\title{
The verification of ECU calibrations of a 1.3 Multijet engine on a chassis dynamometer
}

\begin{abstract}
One of the basic purposes of passenger vehicle engine tests on a chassis dynamometer is to verify the results of the tests carried out on engine test beds in terms of the ECU parameters. The paper presents the analysis of the engine load distribution in driving cycles both European and American. The issue of the influence of selected calibrations of a 1.3 Multijet engine on its operating parameters and the exhaust emissions has been presented. The realization of the project consisted in performing a series of tests on a chassis dynamometer for selected ECU calibrations determined during the engine test bed phase.
\end{abstract}

Key words: diesel engine, engine control, exhaust emission

\section{Weryfikacja doboru kalibracji sterowania silnika 1.3 Multijet na hamowni podwoziowej}

\begin{abstract}
Jednym z podstawowych celów wykonywania badań na hamowniach podwoziowych silników spalinowych stużacych do napędu samochodów osobowych jest weryfikacja prac realizowanych na hamowniach silnikowych w zakresie odpowiedniego doboru parametrów sterujących praca tych silników. W artykule przedstawiono analizę rozkładu obciązeń silników w testach jezdnych, zarówno europejskim, jak i amerykańskim, omówiono zagadnienie weryfikacji wybranych regulacji (kalibracji) silnika 1.3 Multijet na parametry jego pracy i skład spalin. Realizacja tematu sprowadzała się do wykonania badań na hamowni podwoziowej dla wybranych kalibracji sterowania silnika, określonych podczas prac badawczych przeprowadzonych na hamowni silnikowej.
\end{abstract}

Słowa kluczowe: silnik o zapłonie samoczynnym, sterowanie silnika, emisja zanieczyszczeń

\section{Introduction}

One of the quality criteria for a contemporary vehicle engine that decide about its usability and approval for production and, subsequently, legal use is the result of the tailpipe emission tests $\left(\mathrm{NO}_{\mathrm{x}}, \mathrm{HC}\right.$ and $\left.\mathrm{CO}\right)$, performed under conditions of certain speed and time variability, otherwise known as driving cycles $[1,3]$.

As a result of the tests carried out on an engine test bed we can obtain the characteristics of the engine operating parameters in the form of engine performance, fuel consumption and exhaust emissions. This allows getting a full picture of the actual engine parameters. Despite such huge possibilities related to the engine test bed the actual engine usability under road conditions cannot be fully determined. Hence, a final verification of the engine parameters in driving cycles and road tests is necessary (vehicle dynamics and tailpipe emission in particular). The final verification can be performed on a chassis dynamometer which is a simulation of the road test in a variety of conditions. The obtained results may constitute a final evaluation of the engine for real operation $[3,6]$.

The paper presents and discusses the influence of selected calibrations of a 1.3 Multijet on its operating parameters and tailpipe emissions. The realization of the project consisted in performing a series of tests on a chassis dynamometer for selected ECU calibrations, determined during the research works published in $[4,5,6]$ that concerned the appropriate parameter selection for fuel dosage such as: splitting of the

\section{Wprowadzenie}

Jedną z miar jakości współczesnego silnika samochodowego, decydującą o jego walorach użytkowych oraz o dopuszczeniu go do produkcji i eksploatacji na drogach publicznych, jest wynik pomiarów zawartości składników toksycznych w spalinach $\left(\mathrm{NO}_{x}, \mathrm{HC}\right.$ i $\left.\mathrm{CO}\right)$, przeprowadzonych w warunkach określonej zmienności prędkości jazdy i czasu, zwanych cyklem jezdnym [1,3].

W wyniku przeprowadzanych badań na hamowni silnikowej można otrzymać charakterystyki parametrów pracy silnika w postaci osiągów, zużycia paliwa oraz toksyczności spalin. Pozwala to na uzyskanie kompletnego obrazu parametrów pracy silnika. Pomimo tak dużych możliwości w badaniach na hamowni silnikowej, nie można jednoznacznie określić rzeczywistej przydatności silnika do pracy w warunkach drogowych (rzeczywistych). Konieczna zatem jest ostateczna weryfikacja parametrów pracy silnika w warunkach testów jezdnych i badaniach drogowych. Należy mieć na uwadze szczególnie toksyczność spalin i dynamikę pojazdu. Ostateczną weryfikację umożliwiają bowiem badania na hamowni podwoziowej, która stanowi symulację jazdy drogowej w różnych warunkach. Wyniki otrzymywane z tych badań mogą stanowić ostateczną ocenę przygotowania silnika do pracy w warunkach rzeczywistych $[3,6]$.

W artykule przedstawiono i omówiono zagadnienie weryfikacji wybranych regulacji (kalibracji) silnika 1.3 Multijet na parametry jego pracy i skład spalin. Zagadnienie sprowadzało się do wykonania badań na hamowni podwoziowej 
total fuel dose into component fuel doses, the quantity of the individual components and their angles.

\section{The Analysis of the Load Distribution in the Driving Cycles}

Until recently the purpose of engine test beds was limited to perform investigations related to quasi-statistical engine speed, load or calibration characteristics. Various vehicle driving cycles (i.a. NEDC - New European Driving Cycle and American FTP - Federal Test Procedure) used for homologation procedures in the first place are realized on a chassis dynamometer (currently, highly automated). The purpose of these tests is to verify whether the vehicle meets the ecological (tailpipe emissions) and economic requirements (reduction of fuel consumption) under the conditions of a stable speed profile (vehicle speed in the function of time). The above confirms that in this respect the engine takes priority before the drivetrain in the tests [8].

The load ranges of typical engines manufactured for the European and American markets vary substantially (Fig. 1). The analysis of the load distribution in the European driving cycle NEDC allows a statement that the full range of engine speeds and loads is used only to a very limited extent (up to $50 \%$ load and engine speed). The characteristics of the load and engine speed in the FTP75 is very similar. This test is performed for low and medium engine speeds and loads. However, the analyses of the dynamic tests such as ETC (European Transient Test) and USTT (United States

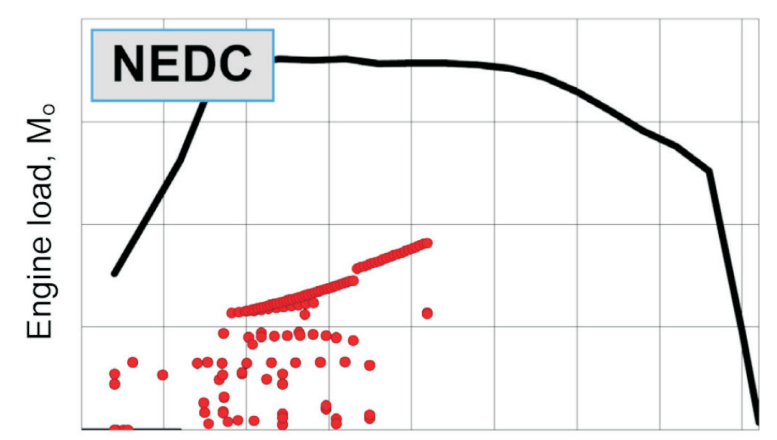

Engine speed, $\mathrm{n}$

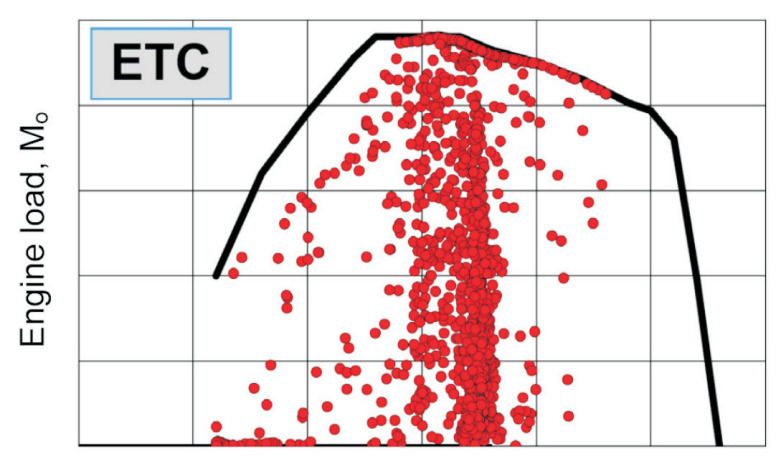

Engine speed, $\mathrm{n}$ dla wybranych kalibracji sterowania silnika, określonych podczas prac badawczych, które byłe przedmiotem publikacji $[4,5,6]$, a dotyczyły odpowiedniego doboru parametrów kształtujących dawkę paliwa, takich jak: podział całkowitej dawki paliwa na dawki składowe, wielkość poszczególnych składowych oraz kąty ich występowania.

\section{Analiza rozkładu obciążeń w testach jezdnych}

Dotychczas hamownia silnikowa służyła niemal wyłącznie do badań quasi-statycznych charakterystyk prędkościowych, obciążeniowych bądź regulacyjnych. Różnorodne testy drogowe pojazdów (m.in. testy NEDC - New European Driving Cycle oraz amerykańskie FTP - Federal Test Procedure), służące przede wszystkim do celów homologacyjnych, są realizowane z wykorzystaniem hamowni podwoziowej (obecnie w dużym stopniu zautomatyzowanej). Zadaniem ich jest sprawdzenie, czy w warunkach ustalonego profilu prędkości (prędkości pojazdu jako funkcji czasu), pojazd spełnia wymagania ekologiczne (ograniczenie emisji składników szkodliwych) i ekonomiczne (ograniczenie zużycia paliwa). Z powyższego wynika, że w badaniach drogowych najistotniejszy jest silnik, a następnie układ jezdny pojazdu [8].

Zakresy obciążeń typowych silników produkowanych na rynki krajów europejskich oraz amerykańskich różnią się znacznie (rys. 1). Analiza rozkładu obciążeń w europejskim teście jezdnym NEDC pozwala na stwierdzenie, że w niewielkim stopniu wykorzystywany jest pełny zakres prędkości

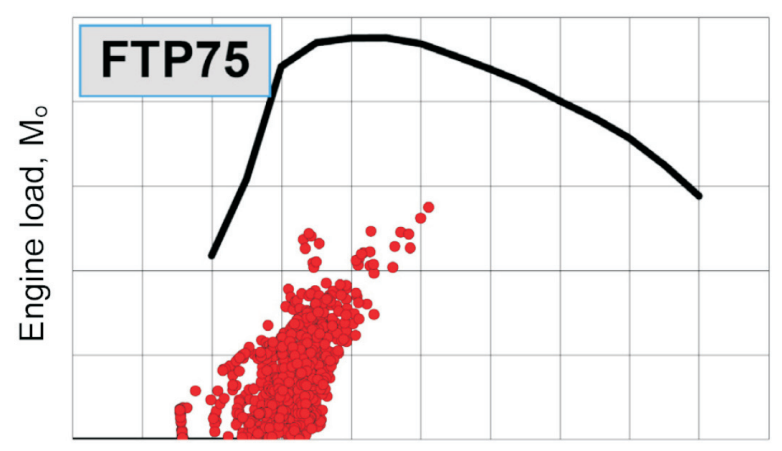

Engine speed, $\mathrm{n}$

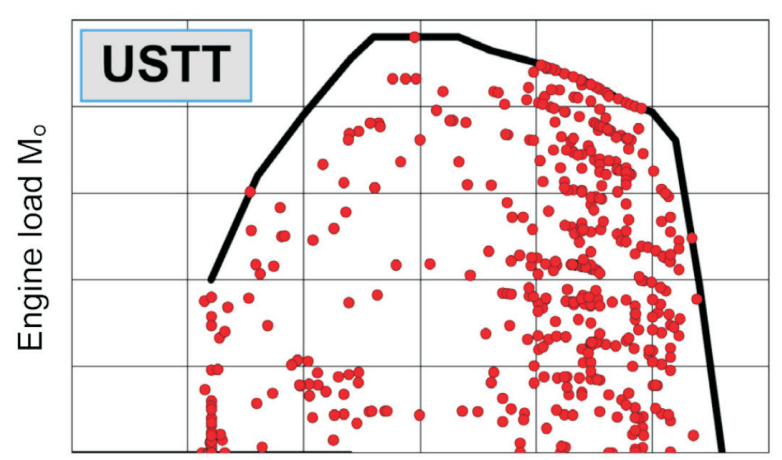

Engine speed, $\mathrm{n}$

Fig. 1. The ranges of engine speeds and loads used in typical driving cycles (on a chassis dynamometer) and stationary cycles (on an engine test bed) [7] Rys. 1. Zakresy prędkości obrotowych i obciązeń wykorzystywanych w typowych testach jezdnych (na hamowni podwoziowej) i stacjonarnych (wykonywanych na hamowni silnikowej) [7] 
Transient Test) used for Heavy Duty Vehicles show that the maximum engine loads are used in a much wider engine speed range (ETC test $-80 \%$ of the maximum engine speed, USTT test - 100\%).

Due to little changes of the loads in the driving cycles very small increments of the value of the mean effective pressure are observed. In the NEDC test the changes reach not more than $0.05 \mathrm{MPa} / \mathrm{s}$. The changes in the engine speed are not abrupt either and they can lead to a conclusion that the engine speed gradients are not high, reaching the level of $500 \mathrm{rpm} / \mathrm{s}$ (this results from a smooth speed profile in this test). The FTP75 is more dynamic in terms of engine speed changes (approximately $750 \mathrm{rpm} / \mathrm{s}$ ), yet, the changes in the mean effective pressure are on a level similar to the European test. The Stationary tests are characterized by a high variability of loads and engine speeds. For the ETC test pe amount to $0.12 \mathrm{MPa} / \mathrm{s}$. The changes in the engine speed are on a level similar to the driving cycles. The USTT test is characterized by the concentration of the values around a central point $\left(\Delta \mathrm{n}=0, \Delta \mathrm{p}_{\mathrm{e}}=0\right)$ (Fig. 2) and the gradients amount to $300 \mathrm{rpm} / \mathrm{s}$ and $0.1 \mathrm{MPa} / \mathrm{s}$ respectively.

\section{Test object and the test stand}

The object of the tests was Fiat Panda fitted with a four cylinder, direct injection DOHC diesel engine with four valves per cylinder. The Fiat turbocharged engine is fitted with an electronic common rail Multijet injection.

The tests were carried out in the Emissions Laboratory at BOSMAL Automotive R\&D Center in Bielsko-Biała on a SCHENCK 500GS/60 chassis dynamometer (Fig. 3). During
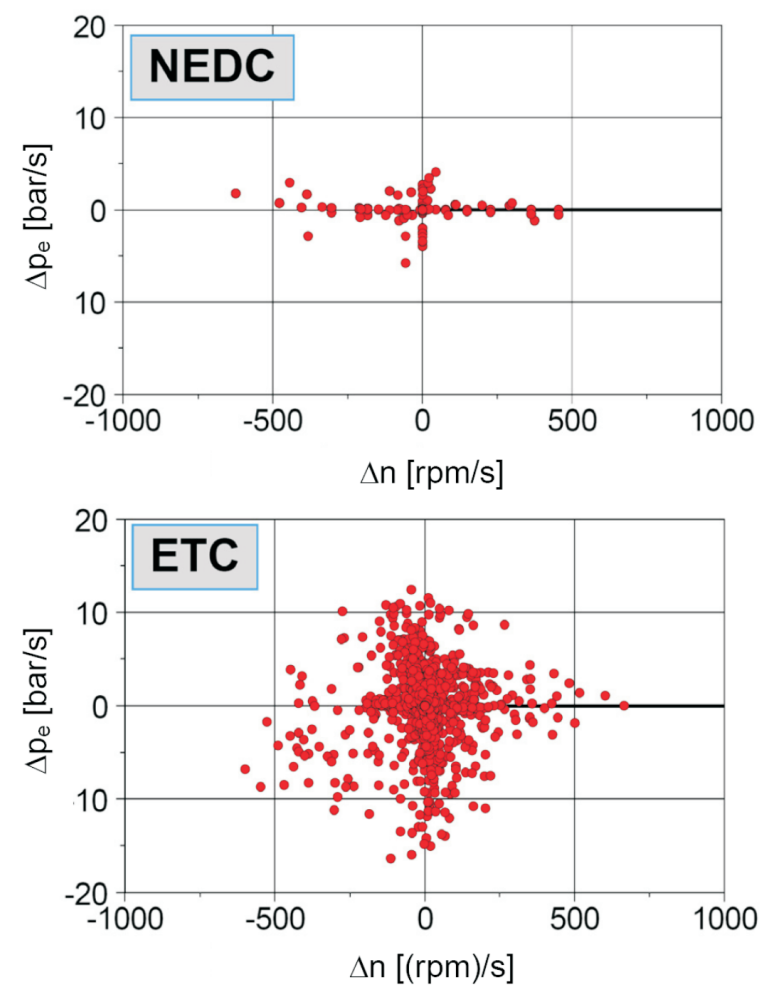

i obciążeń silników (do 50\% obciążenia i prędkości obrotowej). Bardzo podobna jest charakterystyka wykorzystania obciążenia i prędkości obrotowej w teście FTP75. Test ten jest przeprowadzany w zakresie niskich i średnich prędkości obrotowych i obciążeń silnika. Natomiast z analizy testów dynamicznych silników, np. test ETC (European Transient Test - europejski dynamiczny test na hamowni silnikowej) oraz USTT (United States Transient Test - niestacjonarny amerykański test dla silników ZS), stosowanych dla silników pojazdów typu HDV (Heavy Duty Vehicle - wysilone silniki o zapłonie samoczynnym), wynika, że wykorzystywane są maksymalne obciążenia silników w znacznie większym zakresie prędkości obrotowych (w teście ETC - 80\% maksymalnej prędkości obrotowej, w teście USTT - 100\%).

Ze względu na niewielkie zmiany obciążeń w testach jezdnych, obserwuje się również bardzo małe przyrosty wartości średniego ciśnienia efektywnego. W teście NEDC zmiany te wynoszą maksymalnie $0,05 \mathrm{MPa} / \mathrm{s}$. Zmiany prędkości obrotowej również nie są gwałtowne i na ich podstawie można wnioskować o niezbyt dużych gradientach prędkości obrotowej silnika na poziomie 500 (obr/min)/s (co wynika z łagodnego profilu prędkości w tym teście). Test FTP75 jest bardziej dynamiczny pod względem zmian prędkości obrotowej (zmiana około 750 (obr/min)/s), jednak zmiany ciśnienia efektywnego są na poziomie zbliżonym do testu europejskiego. Testy stacjonarne charakteryzują się dużą zmiennością zarówno obciążenia, jak i prędkości obrotowej. Dla testu ETC zmiany pe wynoszą około 0,12 MPa/s. Zmiany prędkości obrotowej są na podobnym poziomie jak w testach jezdnych. Amerykański dynamiczny test sta-
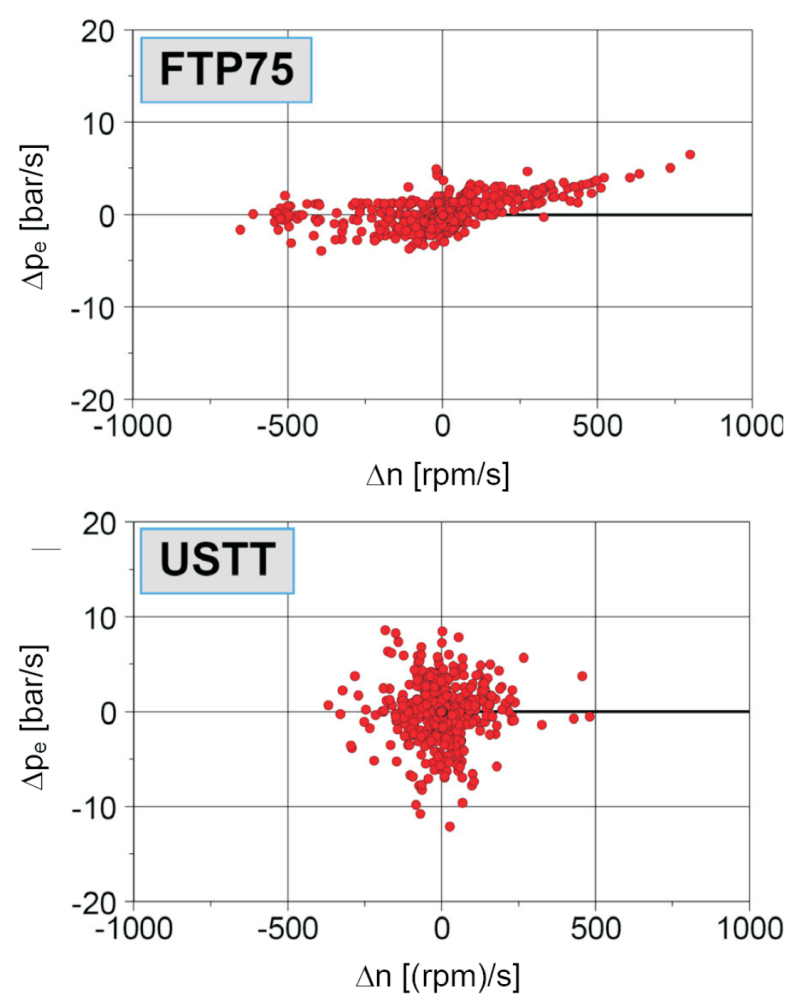

Fig. 2. Dynamics of the driving and stationary cycles [2]

Rys. 2. Dynamika testów jezdnych i stacjonarnych silników [2] 


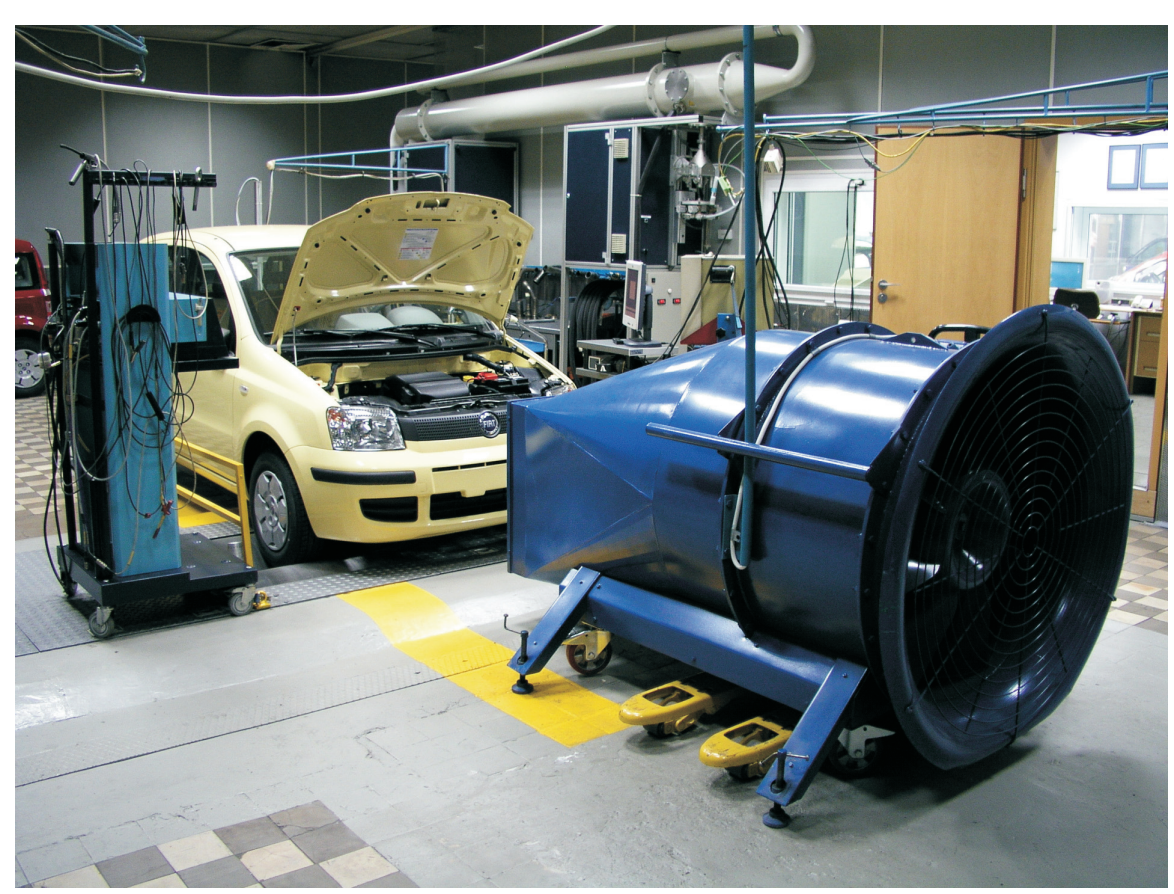

Fig. 3. Chassis dynamometer Rys. 3. Hamownia podwoziowa

the tests a system of exhaust acquisition and sampling was used (CVS-CFV AVL CEC, exhaust gas analyzing set AVL CEB 600 and a test control unit - AVL Cesar.

\section{Test results}

The adjustments of the fuel dose preset in the ECU as selected through the analyses published in [4] were verified and evaluated. The evaluation was executed in two stages.

In the first stage - on a chassis dynamometer points corresponding to the engine operating states within the driving cycle (ECE 83.05 and Directive 98/61/EC) were selected (Fig. 4) for which the vehicle maintains constant speeds (Tab. 1). Such a selection of the engine operating points made it possible to measure the toxic emissions for different fuel dose calibrations. The obtained results could be compared, which enabled an evaluation of the influence of the calibration of the fuel dose on the exhaust emissions and a comparison of these results to the data obtained on the chassis dynamometer. Because the total quantity of the consumed fuel was constant and the vehicle maintained its speed, the engine efficiency remained on a constant level. The distribution of the measuring points on the NEDC driving cycle has been shown in Fig. 5. Three constant cruising speeds were selected: $\mathrm{V}_{1}=50 \mathrm{~km} / \mathrm{h}$ in the third gear, $\mathrm{V}_{2}=70 \mathrm{~km} / \mathrm{h}$ in the fifth gear and $V_{3}=100 \mathrm{~km} / \mathrm{h}$ in the fifth gear.

The second stage of the tests was the evaluation of the vehicle traction with the modified ECU algorithms. For safety reasons, due to a lack of certainty as to the engine behavior in its dynamic states with the modified ECU algorithms the traction tests were also performed on the chassis dynamometer. To this end, acceleration tests were performed at individual gears with a view cjonarny USTT charakteryzuje się skupieniem wartości wokół punktu centralnego $\left(\Delta \mathrm{n}=0, \Delta \mathrm{p}_{\mathrm{e}}=0\right)$ (rys. 2) $\mathrm{i}$ gradienty wynoszą odpowiednio 300 (obr/min)/s oraz $0,1 \mathrm{MPa} / \mathrm{s}$.

\section{Obiekt badań i stanowisko badawcze}

Obiektem badań był samochód Fiat Panda z czterocylindrowym silnikiem o zapłonie samoczynnym z bezpośrednim wtryskiem paliwa o czterech zaworach na cylinder, napędzanych dwoma wałkami rozrządu (DOHC). Silnik doładowany jest zespołem turbosprężarkowym i jest wyposażony w elektronicznie sterowany układ wtryskowy common rail z systemem Multijet.

Badania przeprowadzono w Pracowni Badań Toksyczności Spalin OBR SM BOSMAL w BielskuBiałej, na hamowni podwoziowej typu SCHENCK 500GS/60 (rys. 3). W pomiarach wykorzystano system poboru i próbkowania spalin CVS-CFV typu AVL CEC, zestaw analizatorów spalin AVL CEB 600 i komputerowy system sterujący pomiarami typu AVL Cesar.

\section{Wyniki badań}

Ocenie i weryfikacji podlegały regulacje dawki paliwa zaprogramowane w jednostce sterującej silnika, wytypowane na podstawie analiz przeprowadzonych badań będących tematem publikacji [4]. Ocena przebiegała w dwóch etapach.

W pierwszym - na hamowni podwoziowej wybrano punkty odpowiadające stanom pracy silnika w ramach testu jezdnego (rys. 4) zgodnie z Regulaminem ECE 83.05 i Dyrektywą 98/61/EC, dla których samochód porusza się ze stałymi prędkościami jazdy (tab. 1). Taki dobór punktów pracy silnika umożliwiał pomiar zawartości składników

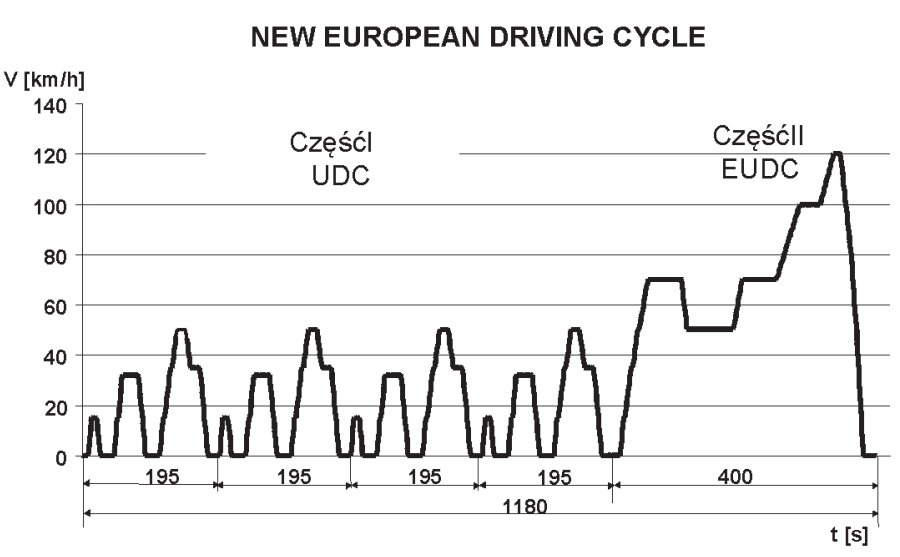

Fig. 4. The course of NEDC (UDC + EUDC)

Rys. 4. Przebieg europejskiego cyklu jezdnego NEDC (UDC + EUDC) 
for each gear undergoing the ECU algorithm modification to cover a substantial engine operating field. The vehicle behavior such as the acceleration and engine smoothness was evaluated during such trials. A subjective opinion of the vehicle driver as well as the results of the acquired speed and acceleration measurement constituted the trial.

Below the results of the first stage of the tests has been presented and discussed. The differences in engine control occurring for individual calibrations have been shown in Table 2. As a result of the modification of the calibration parameters the emissions were measured during the driving cycle. The calibration marked 1 denoted a regular engine calibration, 2 was related to the speeds of 50 and $70 \mathrm{~km} / \mathrm{h}$, and 3 was related to the speed of $100 \mathrm{~km} / \mathrm{h}$ and consisted in an delay of the injection angle by the value at the ,--". The calibration $3(50$ and $70 \mathrm{~km} / \mathrm{h})$ and $2(100 \mathrm{~km} / \mathrm{h})$ consisted in an advance of the injection angle by the value at the ,,+".

The $\mathrm{NO}_{\mathrm{x}}$ level was influenced by the following calibrations: $\mathrm{NO}_{\mathrm{x}}$ increase occurs for the advanced of the injection angle (calibration 3 ) and its decrease for the delayed injection angle (calibration 2). Both the advancement (calibration 3) toksycznych w spalinach dla różnych nastaw regulacyjnych dawki paliwa. Uzyskane w ten sposób wyniki mogły być porównywane, co pozwoliło na ocenę wpływu regulacji dawki paliwa na zmianę składu spalin i odniesienie tych wyników do danych z hamowni silnikowej. Ponieważ całkowita ilość zużywanego paliwa nie ulegała zmianie, jak również samochód poruszał się ze stałą prędkością, sprawność silnika pozostawała na stałym, niezmiennym poziomie. Rozkład punktów pomiarowych na tle testu jezdnego NEDC przedstawiono na rys. 5. Wytypowano trzy stałe prędkości jazdy: $\mathrm{V}_{1}=50 \mathrm{~km} / \mathrm{h}$ na trzecim przełożeniu, $\mathrm{V}_{2}=70 \mathrm{~km} / \mathrm{h}$ na piątym przełożeniu oraz $\mathrm{V}_{3}=100 \mathrm{~km} / \mathrm{h}$ na piątym przełożeniu skrzyni biegów.

Table 1. Selected engine operating points

Tabela 1. Wytypowane punkty pracy silnika

\begin{tabular}{|c|c|c|}
\hline No. & $\begin{array}{c}\text { Cruising speed in NEDC }[\mathrm{km}] / \\
\text { prędkość jazdy w teście NEDC }[\mathrm{km}]\end{array}$ & $\begin{array}{c}\text { Gear/przełożenie } \\
\text { skrzyni biegów }\end{array}$ \\
\hline 1 & 50 & $\mathrm{III}$ \\
\hline 2 & 70 & $\mathrm{~V}$ \\
\hline 3 & 100 & $\mathrm{~V}$ \\
\hline
\end{tabular}

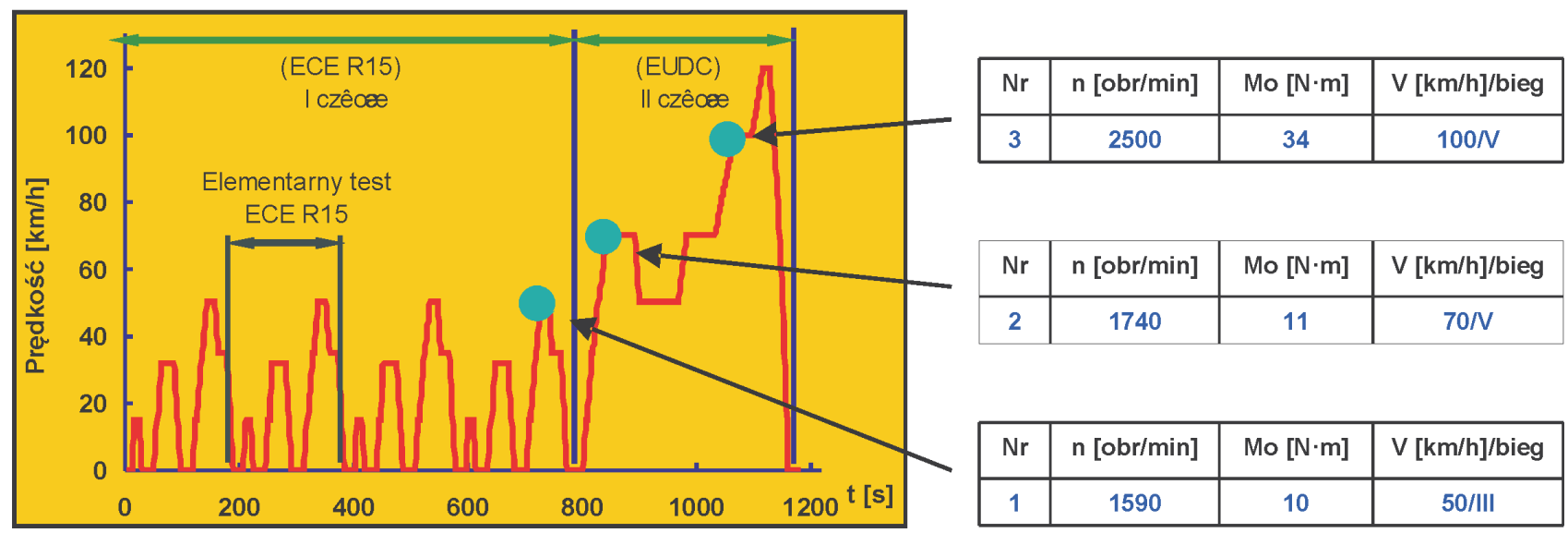

Fig. 5. Distribution of the measuring points in the driving cycle

Rys. 5. Rozkład punktów pomiarowych na tle testu jezdnego

and the delay (calibration 2) of the injection angle have an adverse effect on the level of hydrocarbons (HC level grows). The nature of the $\mathrm{CO}$ concentration variation is analogical to the changes in hydrocarbons, which was discussed above. The calibration changes marked 2 indicate a miniscule increase in the content of hydrocarbons, carbon monoxide and particulate matter while the $\mathrm{NO}_{\mathrm{x}}$ is reduced, which is the most favorable adjustment.

For the speed of $\mathrm{V}_{1}=50 \mathrm{~km} / \mathrm{h}$ and the third gear, following the calibration changes no significant improvement of the toxic component concentration was observed (Fig. 6). A different color denotes the engine operating points with a standard calibration for reference.

For the speed of $\mathrm{V}_{2}=70 \mathrm{~km} / \mathrm{h}$ and the fifth gear as a result of the calibration changes the content of the most of the toxic exhaust components was improved (Fig. 7). As per Table 3, calibration 1 was a standard engine calibration, calibration
Drugim etapem badań była ocena zdolności trakcyjnych pojazdu przy zmodyfikowanych algorytmach sterowania silnikiem. Ze względu na bezpieczeństwo, przejawiające się brakiem pewności co do zachowania silnika w stanach dynamicznych przy zmienionych algorytmach sterowania, badania zdolności trakcyjnych wykonano również na hamowni podwoziowej. W tym celu przeprowadzono próby przyspieszenia na poszczególnych przełożeniach skrzyni biegów, mających na celu objęcie swoim zakresem znaczącego pola pracy silnika, w którym dokonywano modyfikacji algorytmów sterowania silnika. Ocenie podlegało zachowanie się pojazdu podczas takich prób, zdolność przyspieszania i równomierność pracy silnika. Wynikiem była subiektywna ocena prowadzącego pojazd oraz wyniki z akwizycji pomiaru prędkości i przyspieszenia.

Poniżej przedstawiono i omówiono wyniki pierwszego etapu badań. Różnice w sterowaniu silnika występujące dla 
2 denoted a delay in the injection angles and calibration 3 denoted an increase in the main- and pre- injection angle (no pilot injection).

Table 2. Engine control calibration

Tabela 2. Kalibracje sterowania silnikiem

\begin{tabular}{|c|c|}
\hline $\begin{array}{c}\text { Calibration number/ } \\
\text { numer kalibracji }\end{array}$ & $\begin{array}{c}\text { Differences in engine control for individual } \\
\text { calibrations/różnice } \text { w sterowaniu dla poszcze- } \\
\text { gólnych kalibracji }\end{array}$ \\
\hline \multicolumn{2}{|c|}{$\mathrm{V}=50 \mathrm{~km} / \mathrm{h} ;$ III gear/bieg } \\
\hline 1 & Standard adjustment/regulacja standardowa \\
\hline 2 & pilot, pre, main, -3 \\
\hline 3 & $\mathrm{pilot}, \mathrm{pre}, \mathrm{main},+2$ \\
\hline & $\mathrm{V}=70 \mathrm{~km} / \mathrm{h} ; \mathrm{V}$ gear/bieg \\
\hline 1 & Standard adjustment/regulacja standardowa \\
\hline 2 & $\mathrm{pre}, \mathrm{main},-2$ \\
\hline 3 & $\mathrm{pre}, \mathrm{main},+4$ \\
\hline & Standard adjustment/regulacja standardowa \\
\hline 1 & $\mathrm{pre}, \mathrm{main},+2$ \\
\hline 2 & $\mathrm{pre}, \mathrm{main},-4$ \\
\hline 3 &
\end{tabular}

The calibrations consisting in the delay of the injection angle are advantageous for the $\mathrm{NO}_{\mathrm{x}}$ level in the exhaust ( $\mathrm{NO}_{\mathrm{x}}$ reduction). A significant $\mathrm{NO}_{\mathrm{x}}$ growth is seen when the injection angle is substantially advanced (calibration 3 ). The hydrocarbon content in the exhaust for the above calibrations drops for all the said calibrations at the discussed engine operating point and the most advantageous drop in this content occurs for calibration 3 when the injection angle is advanced. A similarity in the changes of the content of hydrocarbons and carbon monoxide can be observed. The content of carbon monoxide decreased as a result of the calibration, yet, due to a particularly low content of this component, the changes are negligible. Calibration 2 is the most appropriate - a drop in all three toxic components occurs at a miniscule increase of PM. At the speed of $\mathrm{V}_{3}$, following the calibration changes an improvement of certain toxic components was achieved (Fig. 8). Similarly to the above discussed engine operating points, also in this case $(\mathrm{V}=100$ $\mathrm{km} / \mathrm{h}$ ) the calibration changes (advancement of the injection angle) have an adverse effect on the $\mathrm{NO}_{\mathrm{x}}$ content in the exhaust.

The presented changes in the content of hydrocarbons and carbon monoxide in the exhaust as a function of the injection angle, again, show a similar nature, however, the influence of these adjustments is negligible as the content level of both components is very little. poszczególnych kalibracji przedstawiono w tab. 2. W wyniku zmiany parametrów kalibracyjnych dokonano pomiarów emisji składników toksycznych w warunkach testu ruchu pojazdu. Kalibracje oznaczone numerem 1 dotyczyły standardowej regulacji silnika, kalibracje oznaczone numerem 2 odnosiły się do prędkości jazdy 50 i $70 \mathrm{~km} / \mathrm{h}$, a kalibracja numer 3 odnosiła się do prędkości jazdy $100 \mathrm{~km} / \mathrm{h}$ i dotyczyła regulacji polegającej na opóźnieniu kąta wyprzedzenia wtrysku o podaną wartość dla znaku ,--". Z kolei kalibracja oznaczona numerem 3 (dla prędkości jazdy 50 i $70 \mathrm{~km} / \mathrm{h}$ ) i kalibracja 2 (dla prędkości jazdy $100 \mathrm{~km} / \mathrm{h}$ ) dotyczyły regulacji polegającej na przyspieszaniu kąta wyprzedzenia wtrysku o podaną wartość dla znaku ,,+".

Dla prędkości $\mathrm{V}_{1}=50 \mathrm{~km} / \mathrm{h}$ i trzeciego przełożenia skrzyni biegów w wyniku zmian kalibracyjnych nie uzyskano znaczącej poprawy stężeń składników toksycznych (rys. 6). Odmiennym kolorem zaznaczono punkt pracy bez kalibracji dla standardowej regulacji jako poziomu odniesienia.

Na poziom zawartości tlenków azotu wpływają dokonane regulacje: wzrost zawartości $\mathrm{NO}_{\mathrm{x}}$ występuje przy zwiększaniu kąta wyprzedzenia wtrysku (kalibracja 3), a zmniejszenie dla opóźnionego kąta wyprzedzenia wtrysku (kalibracja 2). Zarówno zwiększenie kąta wyprzedzenia wtrysku (kalibracja 3), jak i jego zmniejszenie (kalibracja 2) wpływają niekorzystnie na stężenie węglowodorów (powodują ich zwiększenie). Charakter zmian stężenia tlenku węgla w spalinach jest analogiczny do zmian zawartości węglowodorów - co omówiono wyżej. Zmiany kalibracyjne oznaczone numerem 2 wskazują na niewielkie zwiększenie zawartości węglowodorów i tlenku węgla oraz cząstek stałych przy zmniejszeniu zawartości tlenków azotu - co jest nastawą najbardziej odpowiednią.

Dla prędkości $\mathrm{V}_{2}=70 \mathrm{~km} / \mathrm{h}$ i piątego przełożenia skrzyni biegów w wyniku zmian kalibracyjnych uzyskano poprawę większości składników toksycznych (rys. 7). Zgodnie z

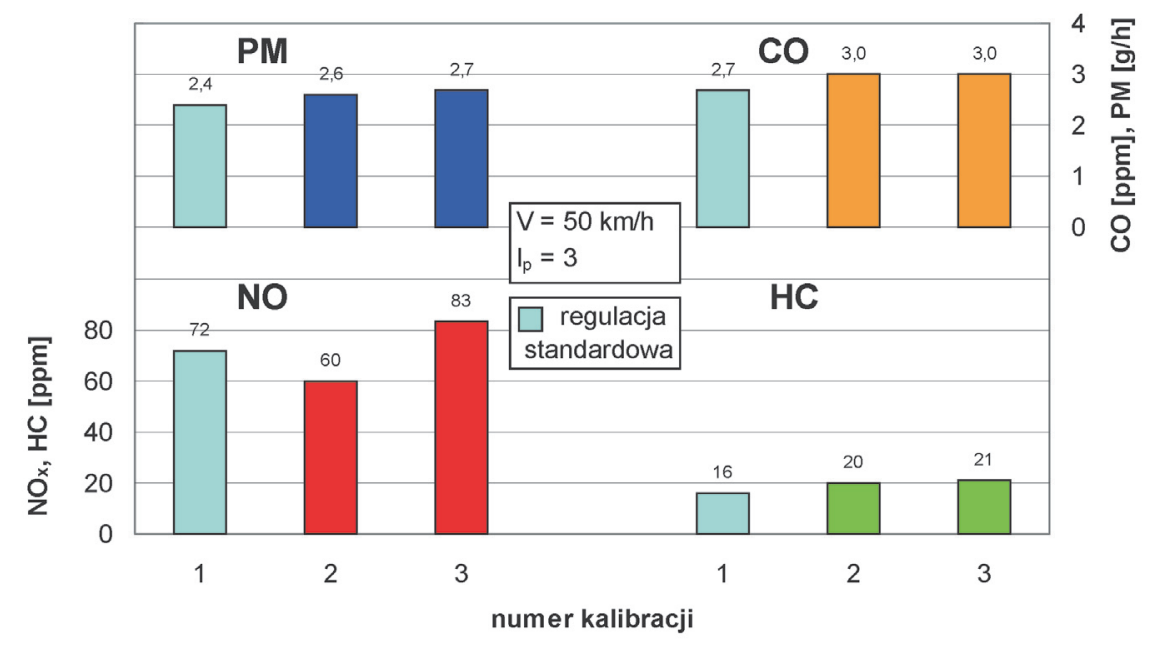

Fig. 6. The influence of the calibration of the injection angle on the toxic emissions at the speed of $\mathrm{V}=50 \mathrm{~km} / \mathrm{h}$ in the third gear

Rys. 6. Wpływ kalibracji kąta wyprzedzenia wtrysku na zmiany zawartości składników szkodliwych spalin przy prędkości $V=50 \mathrm{~km} / \mathrm{h}$ na trzecim przełożeniu skrzyni biegów 


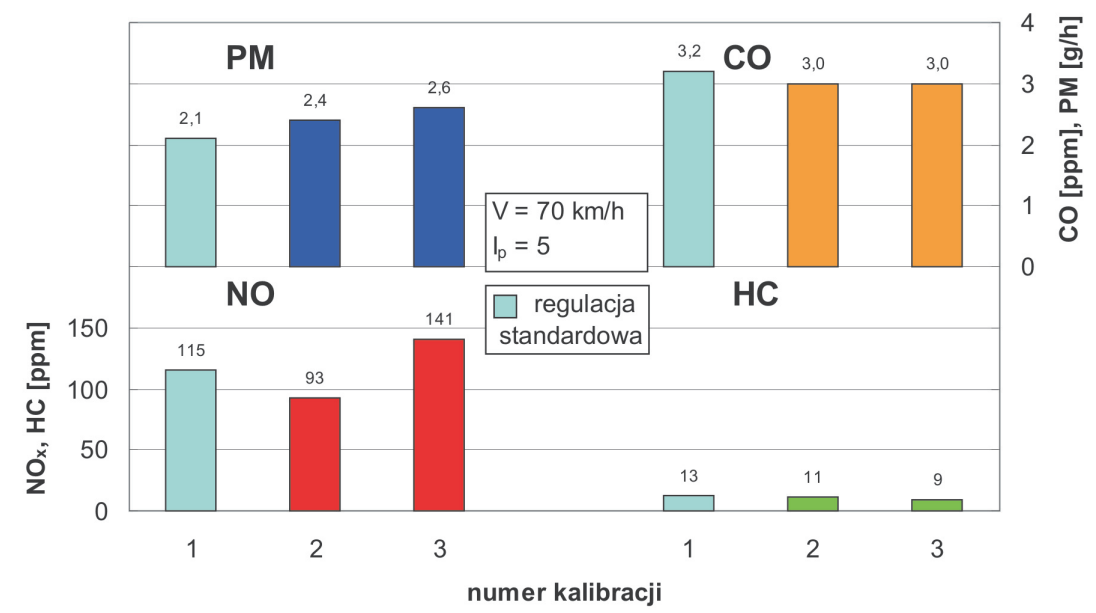

Fig. 7. The influence of the calibration of the injection angle on the toxic emissions at the speed of $\mathrm{V}=70 \mathrm{~km} / \mathrm{h}$ in the fifth gear

Rys. 7. Wpływ kalibracji kąa wyprzedzenia wtrysku na zmiany zawartości skladników szkodliwych spalin przy prędkości $V=70 \mathrm{~km} / \mathrm{h}$ na piąym przełożeniu skrzyni biegów

Calibration 3 is the optimum one - at a small increase of hydrocarbons and carbon monoxide an evident drop in the content of $\mathrm{NO}_{\mathrm{x}}$ and $\mathrm{PM}$ emission takes place.

The tests on the chassis dynamometer allow an evaluation of the injection system adjustments in driving cycle conditions (in this case stable conditions); the following ecological indexes have been obtained (in \%):

a) at the speed of $50 \mathrm{~km} / \mathrm{h}$ in the third gear: decrease in $\mathrm{NO}_{x}$ level by $17 \%$ and increase in PM by $8 \%$,

b) at the speed of $70 \mathrm{~km} / \mathrm{h}$ in the fifth gear: decrease in $\mathrm{NO}_{\mathrm{x}}$ level by $20 \%$, and increase in PM by $14 \%$,

c) at high speeds $(\mathrm{V}=100 \mathrm{~km} / \mathrm{h}$, fifth gear) an $11 \%$ decrease in the PM emissions has been achieved and a $19 \%$ decrease in the $\mathrm{NO}_{\mathrm{x}}$ emission while the content of carbon monoxide and hydrocarbons remained unchanged.

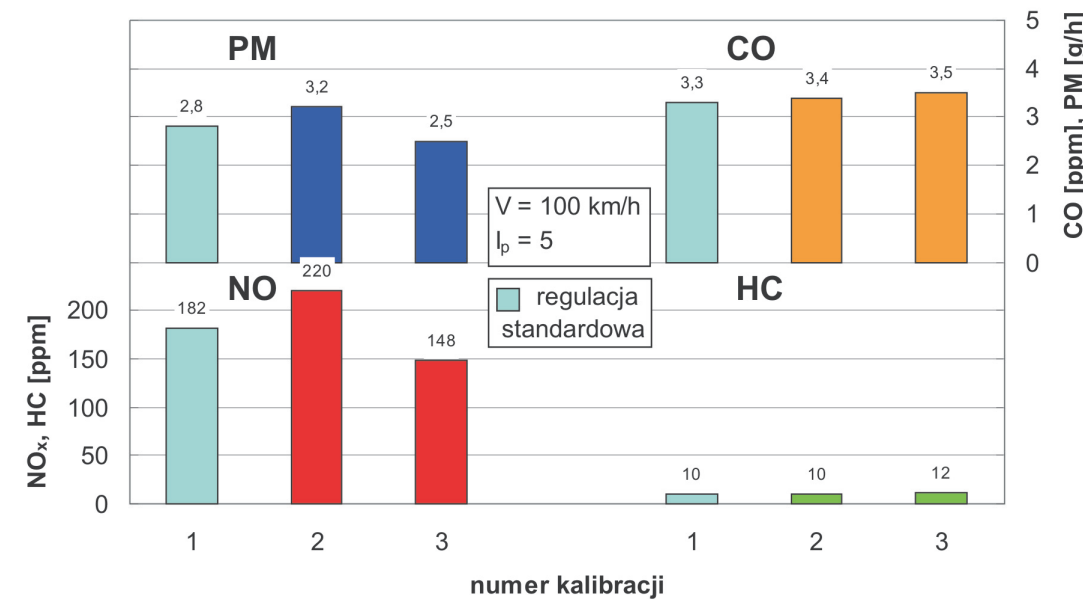

Fig. 8. The influence of the calibration of the injection angle on the toxic emissions at the speed of $\mathrm{V}=100 \mathrm{~km} / \mathrm{h}$ in the fifth gear

Rys. 8. Wplyw kalibracji kąta wyprzedzenia wtrysku na zmiany zawartości składników szkodliwych spalin przy prędkości $V=100 \mathrm{~km} / \mathrm{h}$ na piatym przełożeniu tabelą 3, kalibracja o numerze 1 dotyczy standardowej regulacji silnika, kalibracja 2 jest związana ze zmniejszaniem kąta wyprzedzenia wtrysku, a kalibracja 3 dotyczy wzrostu kąta wyprzedzenia dawki wtrysku main oraz pre (dawka pilot nie występuje).

Zmiany kalibracyjne, polegające na opóźnieniu kąta wyprzedzenia wtrysku, korzystnie wpływają na zawartość tlenków azotu w spalinach, powodując ich obniżenie. Znaczący wzrost zawartości tlenków azotu w spalinach jest wywołany dużym wzrostem kąta wyprzedzenia wtrysku (kalibracja 3). $\mathrm{Z}$ kolei zawartość węglowodorów w spalinach dla przeprowadzonych kalibracji wykazuje zmniejszenie wartości tego składnika dla wszystkich regulacji w omawianym punkcie pracy silnika, przy czym bardziej korzystny spadek ma miejsce $\mathrm{w}$ przypadku kalibracji

3, związanej ze zwiększeniem kąta wyprzedzenia wtrysku. Potwierdza się sytuacja dużej zbieżności w przebiegu zmian zawartości węglowodorów i tlenku węgla w spalinach. Zawartość tlenku węgla w wyniku kalibracji zmalała, jednakże z uwagi na bardzo małą zawartość tego składnika, widoczne zmiany mogą być praktycznie pominięte. Kalibracja 2 jest najbardziej odpowiednią - następuje spadek zawartości wszystkich trzech składników gazowych, przy niewielkim wzroście cząstek stałych. Przy prędkości $V_{3}$ w wyniku zmian kalibracyjnych uzyskano poprawę niektórych składników toksycznych (rys. 8). Podobnie jak dla omówionych wyżej punktów pracy silnika, również $\mathrm{w}$ tym przypadku $(\mathrm{V}=100$ $\mathrm{km} / \mathrm{h}$ ) zmiany kalibracyjne, powodujące zwiększenie kąta wyprzedzenia wtrysku, negatywnie oddziałują na zawartość tlenków azotu w spalinach.

Przedstawione zmiany zawartości węglowodorów oraz tlenku węgla w spalinach jako funkcji kalibracji kąta wyprzedzenia wtrysku ponownie wykazują podobny charakter zmian, przy czym wpływ tych regulacji jest znikomy, biorąc pod uwagę bardzo mały poziom zawartości obu składników. Kalibracja oznaczona numerem 3 jest najbardziej optymalna - przy nieznacznym wzroście zawartości węglowodorów i tlenku węgla następuje wyraźny spadek zawartości tlenków azotu i cząstek stałych.

Badania na hamowni podwoziowej pozwalają ocenić prawidłowość nastaw układu wtryskowego w warunkach jezdnych (w tym przypadku - warunkach ustalonych): uzyskano następujące wskaźniki ekologiczne (procentowe): 


\section{Conclusions}

The tests performed on the chassis dynamometer (after engine fitting into the vehicle) confirmed the results obtained during earlier chassis dynamometer tests in terms of the influence of the fuel dose modification on the exhaust emissions. Through a modification of the engine control algorithms a decrease in the content of $\mathrm{NO}_{\mathrm{x}}$ has been achieved with a miniscule increase in the content of hydrocarbons and PM while the engine efficiency remained unchanged. The obtained results indicate that the tests performed on the engine test bed (stable engine conditions) are fully confirmed by the tests performed on the chassis dynamometer. Hence, it allows a reduction in the research costs that are very high as regards the chassis dynamometer tests. However, one should not forget about the dynamic states of the engine operation during the driving cycles whose realization on the engine test bed is still a difficult and costly task.

Conclusions from the tests:

1. The modification of the standard calibration led to a decrease in the $\mathrm{NO}_{x}$ emissions.

2. A simultaneous reduction of $\mathrm{NO}_{\mathrm{x}}$ and $\mathrm{PM}$ took place at a small increase in the content of $\mathrm{C} O$ and HC.

The presented analyses prove a huge potential of high pressure injection systems whose unlimited calibration possibilities allow a reduction of the toxic components and noise as well as a selection of an appropriate engine torque).

\section{Artykut rercenzowany}

\section{Bibliography/Literatura}

[1] Bielaczyc P., Merkisz J., Pielecha J.: Stan cieplny silnika spalinowego a emisja związków szkodliwych. Wydawnictwo Politechniki Poznańskiej, Poznań 2001.

[2] Körfer T., Herrmann O.E., Lamping M., Ruhkamp L., Pischinger S., Schnorbus T.: Advanced, robust control strategies for precise emission control of diesel engines during highly dynamic test cycles. 28. Internationales Wiener Motorensymposium, Wiedeń 2007.

[3] Merkisz J.: Ekologiczne problemy silników spalinowych, tom 1 i 2. Wydawnictwo Politechniki Poznańskiej, Poznań 1999.

[4] Pietras D., Świątek P.: Dobór kalibracji sterowania silnika 1.3 Multijet w aspekcie jego osiągów i składu spalin. Silniki Spalinowe 2/2008.

[5] Pietras D., Świątek P., Świątek A.: Ocena wpływu przebiegu dawki paliwa na wybrane parametry pracy i skład spalin silnika 1.3 Multijet. PTNSS P07-C008, Silniki Spalinowe 2007-SC1, Poznań-Bielsko-Biała 2007.

[6] Pietras D., Sobieszczański M., Świątek A., Pajdowski P.: Dobór parametrów pracy silnika 1.3 Multijet charakterystycznych dla testu jezdnego NEDC do badań rozwojowych. PTNSS P05-C065, PTNSS Kongres, Szczyrk 2005.

[7] Suzuki M., Tsuzuki N., Teramachi Y.: The new Toyota L-4 direct-injection diesel engine - Toyota D-4D Clean Power Concept. 26. Internationales Wiener Motorensymposium, Wiedeń 2005.

[8] Wituszyński K.: Testowanie silników spalinowych na hamowni silnikowej. Czasopismo Techniczne. Mechanika z. 7-M/2000. Wydawnictwo Politechniki Krakowskiej, Kraków 2000 a) przy prędkości $50 \mathrm{~km} / \mathrm{h}$ na III biegu: zmniejszenie tlenków azotu o 17\% przy jednoczesnym zwiększeniu emisji cząstek stałych o $8 \%$,

b) przy prędkości $70 \mathrm{~km} / \mathrm{h}$ i V biegu uzyskano zmniejszenie tlenków azotu o $20 \%$, przy jednoczesnym zwiększeniu emisji cząstek stałych o 14\%,

c) w zakresie wysokich prędkości jazdy (V=100 km/h na V biegu) uzyskano 11-procentowe zmniejszenie emisji cząstek stałych i jednocześnie 19-procentowe zmniejszenie stężenia tlenków azotu przy braku zmian stężenia tlenku węgla i węglowodorów.

\section{Podsumowanie}

Przeprowadzone badania na hamowni podwoziowej (po zabudowie silnika w samochodzie) potwierdziły wyniki uzyskiwane we wcześniejszych badaniach na hamowni silnikowej, co do wpływu kształtowania dawki paliwa na zawartość składników toksycznych w spalinach. Dokonując modyfikacji algorytmu sterowania silnikiem, uzyskano zmniejszenie zawartości tlenków azotu w spalinach przy niezmienionej sprawności silnika i przy znikomym wzroście zawartości węglowodorów i cząstek stałych. Uzyskane wyniki wskazują na to, że badania przeprowadzone na hamowni silnikowej (w ustalonych warunkach pracy silnika) znajdują w pełni potwierdzenie w badaniach realizowanych na hamowni podwoziowej. Pozwala to tym samym na ograniczenie kosztów prac badawczych, które są bardzo wysokie w przypadku realizacji badań na hamowniach podwoziowych. Należy jednakże pamiętać o stanach dynamicznych pracy silnika podczas wykonywania testów jezdnych, których realizacja na hamowniach silnikowych jest nadal trudnym i kosztownym zadaniem.

Wnioski wynikające z badań:

1. W wyniku dokonanych kalibracji zawartość tlenków azotu wyraźnie malała w stosunku do standardowej regulacji silnika.

2. Możliwe było równoczesne zmniejszenie zawartości tlenków azotu i cząstek stałych przy niewielkim wzroście stężenia CO i HC.

Przedstawione analizy świadczą o dużym potencjale wysokociśnieniowych układów wtryskowych, których dowolne sterowanie (kształtowanie procesu wtrysku) pozwala na osiągnięcie zamierzonych celów (w postaci zmniejszenia emisji składników toksycznych oraz generowanego hałasu, a także kształtowania momentu obrotowego silnika spalinowego).

Prof. Jerzy Merkisz, DSc., DEng. - Professor in the Faculty of Working Machines and Transportation at Poznan University of Technology.

Prof. dr hab. inż. Jerzy Merkisz-profesor na Wydziale Maszyn Roboczych i Transportu Politechniki Poznańskiej. e-mail: jerzy.merkisz@put.poznan.pl

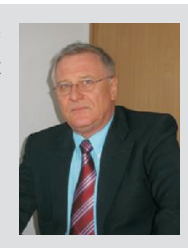

Mr. Piotr Świątek, DEng. - Leader Product Engineering, GM Project Office at FIAT-GM Powertrain Polska sp. z o.o.

Drinż. Piotr Świątek-inż. ds. badańw FIAT-GMPowertrain Polska sp. z o.o.

e-mail:piotr.swiatek@pl.gm.com 